\title{
Stability Indicating Method Development and Validation of Ranolazine Extended Release Tablets
}

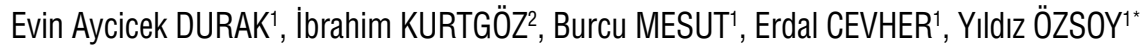 \\ 1 Istanbul University, Faculty of Pharmacy, Pharmaceutical Technology Dept., Beyazit, Istanbul, Turkey \\ 2 Biopharma Pharmaceutical, Istanbul, Turkey
}

\begin{abstract}
The objective of this study was to develop and validate the stability-indicating method for newly developed Extended-Release tablet formulation of Ranolazine. First, new Ranolazine tablet formulation was developed. These tablets were analyzed by using a High-Performance Liquid Chromatography system with a UV detector at $220 \mathrm{~nm}$ wavelength and by using C8-3 column ( $150 \mathrm{~mm} \times 4.6 \mathrm{~mm}$ i.d; $5 \mu \mathrm{m}$ particle size). The injection volume of the system was $10 \mu \mathrm{l}$. The validation parameters; Selectivity, linearity, accuracy, robustness, precision and limit of quantification and detection parameters were proved good results. A highly sensitive and simple HPLC-UV analytical method of the Ranolazine tablet formulation was developed in accordance with ICH Guideline Q2 and Q3.
\end{abstract}

Keywords: Ranolazine, HPLC, forced degradation, stability indicating method, validation

\section{INTRODUCTION}

Ranolazine, (RNZ, N-(2,6-dimethylphenyl)-2-\{4-[2-hydroxy-3-(2-methoxyphenoxy) propyl] piperazine-1-yl $\}$ acethamide) is a piperazine derivative drug substance, which has anti-ischemic and antianginal effects ${ }^{1-3}$. The chemical structure of $\mathrm{RNZ}^{4}$ is given in Figure 1. RNZ is a stereo isomer molecule. The pharmacological activity of enantiomers shows statistically insignificant differences ${ }^{5,6}$.

\footnotetext{
${ }^{*}$ Corresponding author:

Yıldız Özsoy

Istanbul University, Faculty of Pharmacy, Pharmaceutical Technology Dept., Beyazit. yozsoy@istanbul.edu.tr ORCIDs:

Evin Ayçiçek Durak: 0000-0003-0724-6698

Ibrahim Kurtgöz: 0000-0002-0836-8622

Burcu Mesut: 0000-0003-2838-1688

Erdal Cevher: 0000-0002-0486-2252

Yıldız Özsoy: 0000-0002-9110-3704

(Received 05 November 2020, accepted 03 December 2020)
} 


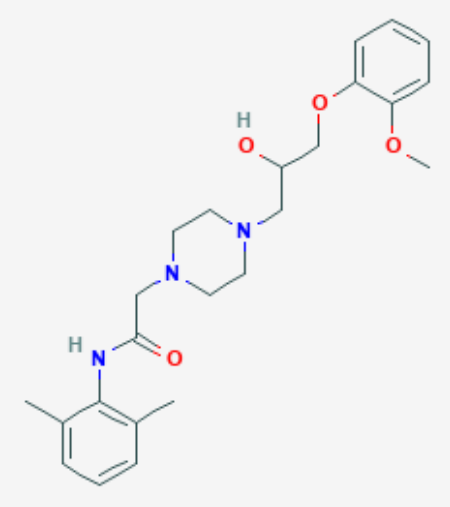

Figure 1. The chemical structure of RNZ

In the past decades, RNZ is the only anti arrhythmic medication developed and marketed for the treatment of chronic angina7. RNZ inhibits selectively fast and late sodium current. RNZ is a well-tolerated drug without showing any bradycardia and/or hypotension effect in contrast to $\beta$-blockers, $\mathrm{Ca}^{++}$blockers, and nitrates $^{8,9}$. Although there is no convincing proof, RNZ has been shown to improve glycometabolic homeostasis in rats by enhancing insulin function ${ }^{10,11}$.

Many patients sustain persistent angina, despite the using combined drug therapies ${ }^{12}$. In some cases, the use of additional antianginal agents with a novel mechanism of action, such as RNZ, is unavoidable. RNZ extended release (ER) tablets are developed and marketed due to the short half-life of RNZ immediate release tablets. Because of the increasing consumption of RNZ, separate chromatographic methods for its analysis were reported in the literature. There is no official monograph for RNZ in the pharmacopoeias, in this context developing and validating stability indicating chromatographic method could be useful.

The aim of developing RNZ ER tablets is to reduce the severity and frequency of angina pectoris symptoms and improving the life standard of patient ${ }^{13}$. Common granulation techniques such as wet and dry granulation were used to prepare RNZ ER tablets, indicated in the literature. The effect of different $\mathrm{pH}$-dependent $\mathrm{t}^{14-16}$ and/or $\mathrm{pH}$-independent polymers on the release of RNZ ER tablets were observed ${ }^{17-19}$ in these studies.

The objective of this study was developing and validating stability indicating method for prepared ER tablet formulation of RNZ. The developed method was validated RNZ and its impurities. The proposed chromatographic method was applied to the assay of commercial Ranexa ER tablet and prepared RNZ ER tablet. 


\section{METHODOLOGY}

\section{Chemical, reagents and materials}

Ranolazine, Ranolazine Working Standard (WS), Zen-I Impurity WS, Zen-II Impurity WS, and Zen-III Impurity WS were purchased from Aarti Healthcare (Mumbai-India). Acetonitrile, methanol, hydrochloric acid, perchloric acid, phosphoric acid, ammonium dihydrogen phosphate, sodium hydroxide, ethanol, and triethylamine were purchased from J.T.Baker (AP-USA). Fumaric acid was a kind gift from Merck Millipore (Darmstadt-Germany). Povidon (Kollidon ${ }^{\circledR}$ K30) was purchased from BASF (Florham Park-USA). Xanthan gum was purchased from CP-Kelco (USA). Hypromellose (Benecel ${ }^{\mathrm{TM}} \mathrm{K} 15 \mathrm{M}$ ) was a gift from Ashland (Covington-USA). Magnesium stearate was purchased from Faci (Carasco GE Italy).

\section{Preparation of RNZ ER tablets}

RNZ 500 mg ER tablets were prepared by wet granulation method. The high shear mixer was used for granulation. The granulation process designed in two stages. At the first stage, fumaric acid and Ranolazin were granulated with granulation solvent consist of purified water and PVP. The wet mass sieved and dried in the oven. Afterward, dried bulk was sieved and this premix blended with hypromellose and xanthan gum. The second granulation was carried out with ethanol. The wet mass sieved and dried in the oven. The dried mass eluted and mixed with magnesium stearate to obtain the final blend. The unit formula and the function of the raw materials of RNZ ER tablets are shown at the Table 1. The final blend was compressed by using rotary tablet press machine (Manesty XSpress).

Table 1. The unit formula and the function of the raw materials of RNZ ER tablet

\begin{tabular}{|c|c|c|}
\hline Raw materials & Function & $\% w / w$ \\
\hline Ranolazine & Active ingredient & 63,69 \\
\hline Fumaric acid & Diluent & 25,48 \\
\hline Povidon & Binder & 2,42 \\
\hline Hypromellose & Controlled release agent & 2,04 \\
\hline Xanthan gum & Controlled release agent & 5,10 \\
\hline Magnesium stearate & Lubricant & 1,27 \\
\hline Purified water ${ }^{*}$ & Granulation solvent & - \\
\hline Ethanol ${ }^{*}$ & Granulation solvent & - \\
\hline
\end{tabular}

*purified water and ethanol were used as granulation solvent and do not exist in the finished product. 


\section{Instrumentation and analytical conditions}

Analysis method of RNZ and its impurities were chromatographic. A Waters High Performance Liquid Chromatography (HPLC) system (New Castle-USA) with UV detector was used. The method validation was made in accordance with ICH Guideline Q2 and Q3 ${ }^{20,21}$.

\section{Chromatographic condition for quantization of RNZ}

Inertsil C8-3 column ( $150 \mathrm{~mm} \times 4.6 \mathrm{~mm}$ i.d; $5 \mu \mathrm{m}$ particle size) from GL Sciences (Japan), was performed for chromatographic separation of RNZ. The temperature of column was set and maintained at $30^{\circ} \mathrm{C}$. The UV detection was fixed to $220 \mathrm{~nm}$ wavelength and the injection volume was $10 \mu$. The mobile phase was consisting of acetonitrile (A) and buffer solution (B) (30:70). Buffer solution was prepared with triethylamine: purified water; 4.2:1000 (v/v) and the $\mathrm{pH}$ of solution was adjusted to $3.00 \pm 0.05$ with phosphoric acid. The flow rate was set to $1.0 \mathrm{ml} / \mathrm{min}$. The injection time was 9 minutes.

\section{Chromatographic condition for quantization of impurities}

Waters XTerra RP18 column ( $250 \mathrm{~mm}$ x $4.6 \mathrm{~mm}$ i.d; $5 \mu \mathrm{m}$ particle size) from Waters (New Castle-USA), was performed for chromatographic separation of Zen-I (2-((2-methoxyphenoxy) methyl) oxirane), Zen-II (2-chloro-N-(2,6dimethylphenyl) acetamide), and Zen-III, RNZ impurities. The UV detection was fixed to $210 \mathrm{~nm}$ wavelength and the injection volume was $20 \mu \mathrm{l}$. The mobile phase $\mathrm{X}$ was consisting of ammonium dihydrogen phosphate solution (C) and methanol (D) (80:20). The mobile phase $\mathrm{Y}$ was consisting of ammonium dihydrogen phosphate solution (C) and methanol (D) (20:80). Ammonium dihydrogen phosphate solution was prepared with ammonium dihydrogen phosphate: purified water; 5.75:1000 (w/v) and filtered (0.45 $\mu \mathrm{m}$ PET filter). The injection time was 40 minutes. The following gradient, at a fixed flow rate of $1.0 \mathrm{ml} / \mathrm{min}$ was used: from o to $5 \mathrm{~min}$ the composition was $\mathrm{X}: \mathrm{Y}$, 90:10. From 5 to $15 \mathrm{~min}$ the composition was $\mathrm{X}: \mathrm{Y}, 80: 20$. From 15 to $27 \mathrm{~min}$ the composition was X: Y, 40:60. From 27 to $32 \mathrm{~min}$ the composition was X: Y, 20:80. From 32 to 40 min the composition was $\mathrm{X}: \mathrm{Y}, 90: 10$.

\section{Preparation of standard and sample solutions}

\section{Preparation of standard and sample solutions for validation of RNZ}

Preparation of standard solution: $50 \mathrm{mg}$ RNZ WS was accurately weighed to a $20 \mathrm{ml}$ volumetric flask and then $10 \mathrm{ml} 0.1 \mathrm{~N} \mathrm{HCl}$ solution was added to the flask, mixed 1 min by vortex and then kept in an ultrasonic bath during 15 min to obtain a clear solution. The volumetric flask was complemented to designated 
volume with $0.1 \mathrm{~N} \mathrm{HCl}$ solution. $5.0 \mathrm{ml}$ of this solution precisely was transferred to a $50 \mathrm{ml}$ volumetric flask and complemented to designated volume with the mobile phase. The obtained solution was filtered $0.45 \mu \mathrm{m}$ PET filter and transferred to HPLC vials (the concentration of solution $0.25 \mathrm{mg} / \mathrm{ml}$ ).

Preparation of sample solution: 20 RNZ ER tablets were weighed and pulverized by grinding with the help of mortar and pestle. The obtained powder, equivalent to $250 \mathrm{mg} \mathrm{RNZ}$ was accurately weighed and transferred to a $100 \mathrm{ml}$ volumetric flask. The volumetric flask was complemented to designated volume with the mobile phase. The obtained solution was filtered $0.45 \mu \mathrm{m}$ PET filter and transferred to HPLC vials (the concentration of solution $0.25 \mathrm{mg} / \mathrm{ml}$ ).

Preparation of $R N Z$ standard stock solution: $125 \mathrm{mg}$ RNZ WS was accurately weighed to a $50 \mathrm{ml}$ volumetric flask and, then $25 \mathrm{ml} 0.1 \mathrm{~N} \mathrm{HCl}$ solution was added to the flask, mixed 1 min by vortex and then kept in an ultrasonic bath during $15 \mathrm{~min}$ to obtain a clear solution. The volumetric flask was complemented to designated volume with $0.1 \mathrm{~N} \mathrm{HCl}$ solution (the concentration of solution $2.5 \mathrm{mg} / \mathrm{ml})$.

\section{Preparation of standard and sample solution for validation of impurities}

Preparation of RNZ standard solution: $20 \mathrm{mg}$ RNZ WS was accurately weighed to a $50 \mathrm{ml}$ volumetric flask and then $30 \mathrm{ml}$ mobile phase $\mathrm{X}$ solution was added to the flask, mixed $1 \mathrm{~min}$ by vortex. $5.0 \mathrm{ml}$ of this solution precisely was transferred to a $50 \mathrm{ml}$ volumetric flask and complemented to designated volume with mobile phase X. $5.0 \mathrm{ml}$ of this solution precisely was transferred to a $50 \mathrm{ml}$ volumetric flask and complemented to designated volume with the mobile phase $\mathrm{X}$. The obtained solution was filtered $0.45 \mu \mathrm{m}$ PET filter and transferred to HPLC vials (the concentration of solution $0.002 \mathrm{mg} / \mathrm{ml}$ ).

Preparation of placebo solution:124 mg RNZ ER tablet placebo was weighed to a $100 \mathrm{ml}$ volumetric flask and, then $70 \mathrm{ml}$ mobile phase $\mathrm{X}$ solution was added to the flask, and kept in an ultrasonic bath during $10 \mathrm{~min}$. The volumetric flask was complemented to designated volume with the mobile phase X solution and kept in an ultrasonic bath during $10 \mathrm{~min}$. The obtained solution was filtered $0.45 \mu \mathrm{m}$ PET filter and transferred to HPLC vials.

Preparation of sample solution: The pulverized RNZ ER tablets, equivalent to $200 \mathrm{mg}$ RNZ was accurately weighed and transferred to a $100 \mathrm{ml}$ volumetric flask and, then $70 \mathrm{ml}$ mobile phase $\mathrm{X}$ solution was added to the flask and kept in an ultrasonic bath during $10 \mathrm{~min}$. The volumetric flask was complemented to designated volume with mobile phase $\mathrm{X}$ solution and kept in an ultrasonic bath 
for $10 \mathrm{~min}$. The obtained solution was filtered $0.45 \mu \mathrm{m}$ PET filter and transferred to HPLC vials (the concentration of solution $2.0 \mathrm{mg} / \mathrm{ml}$ ).

Preparation of Zen-I, Zen-II, and Zen-III standard stock solution: $7.5 \mathrm{mg}$ ZenI WS was accurately weighed to a $25 \mathrm{ml}$ volumetric flask and then $10 \mathrm{ml}$ mobile phase $\mathrm{X}$ solution was added to the flask, and kept in an ultrasonic bath during $15 \mathrm{~min}$. The volumetric flask was complemented to designated volume with mobile phase $\mathrm{X}$ solution and mixed by a vortex (the concentration of solution 0.3 $\mathrm{mg} / \mathrm{ml}$ ). The same procedure was applied to obtain Zen-II and Zen-III standard stock solutions.

Preparation of $100 \%$ preparative sample solution: The pulverized RNZ ER tablets, equivalent to $200 \mathrm{mg}$ RNZ was accurately weighed and transferred to a $100 \mathrm{ml}$ volumetric flask and then $70 \mathrm{ml}$ mobile phase $\mathrm{X}$ solution was added to the flask and kept in an ultrasonic bath during $10 \mathrm{~min}$. From each standard stock solutions respectively Zen-I, Zen-II, and Zen-III, 1.0 ml solution were added to the flask and complemented to designated volume with the mobile phase $\mathrm{X}$ solution and kept in an ultrasonic bath during $10 \mathrm{~min}$. The obtained solution was filtered $0.45 \mu \mathrm{m}$ PET filter, and transferred to $\mathrm{HPLC}$ vials $\left(\mathrm{C}_{\mathrm{RNZ}}: 2.0\right.$ $\mathrm{mg} / \mathrm{ml}, \mathrm{C}_{\text {ZEN-I }}: 0.003 \mathrm{mg} / \mathrm{ml}, \mathrm{C}_{\text {ZEN-II }}: 0.003 \mathrm{mg} / \mathrm{ml}, \mathrm{C}_{\text {ZEN-III }}: 0.003 \mathrm{mg} / \mathrm{ml}$ ).

Preparation of $200 \%$ preparative sample solution: The pulverized RNZ ER tablets, equivalent to $200 \mathrm{mg}$ RNZ was accurately weighed and transferred to a $100 \mathrm{ml}$ volumetric flask and then $70 \mathrm{ml}$ mobile phase $\mathrm{X}$ solution was added to the flask and kept in an ultrasonic bath during $10 \mathrm{~min}$. From each standard stock solution respectively Zen-I, Zen-II, and Zen-III, $2.0 \mathrm{ml}$ solution were added to the flask and complemented to designated volume with mobile phase $\mathrm{X}$ solution and kept in a ultrasonic bath during $10 \mathrm{~min}$. The obtained solution was filtered $0.45 \mu \mathrm{m}$ PET filter, and transferred to HPLC vials $\left(\mathrm{C}_{\mathrm{RNZ}}: 2.0 \mathrm{mg} / \mathrm{ml}\right.$, $\left.\mathrm{C}_{\text {ZEN-I }}: 0.006 \mathrm{mg} / \mathrm{ml}, \mathrm{C}_{\text {ZEN-II }}: 0.006 \mathrm{mg} / \mathrm{ml}, \mathrm{C}_{\text {ZEN-III }}: 0.006 \mathrm{mg} / \mathrm{ml}\right)$.

\section{Method validation protocol}

Analytical method validation is done to demonstrate that the obtained results are precise and valid and to show the applicability of the method. The stabilityindicating method was validated according to ICH Guidelines Q2 and Q3. In this context linearity, selectivity, accuracy, robustness, precision, the limit of quantification and detection were evaluated.

\section{Forced degradation studies}

Forced degradation studies were performed to prove the stability indicating capability of the method. Prepared samples and placebos were exposed to: 
Acidic condition ( $1 \mathrm{~N} \mathrm{HCl}$ / room temperature for 24 hours)

Basic condition ( $1 \mathrm{~N} \mathrm{NaOH} /$ room temperature for 24 hours)

Oxidative condition $\left(\mathrm{H}_{2} \mathrm{O}_{2} 30 \%\right.$ / room temperature for 24 hours $)$

Thermal condition $\left(60^{\circ} \mathrm{C} \pm 2{ }^{\circ} \mathrm{C} /\right.$ for 1 week $)$

Light (1.2 million lux hours)

\section{Acidic condition}

The pulverized RNZ ER tablets, equivalent to $200 \mathrm{mg}$ RNZ was weighed to a $100 \mathrm{ml}$ volumetric flask and then $20 \mathrm{ml}$ ammonium dihydrogen phosphate solution was added to the flask and kept in an ultrasonic bath during $15 \mathrm{~min}$. Then $10 \mathrm{ml}$ methanol was added to the flask and kept in ultrasonic bath for $1 \mathrm{~min}$. Afterward $15.0 \mathrm{ml} 1 \mathrm{~N} \mathrm{HCl}$ was added. The prepared solution-maintained room temperature for 24 hours. At the end of time the solution was neutralized with $15.0 \mathrm{ml} 1 \mathrm{~N} \mathrm{NaOH}$ and the volumetric flask was complemented with ammonium dihydrogen phosphate solution to designated volume. The flask was kept in an ultrasonic bath for $15 \mathrm{~min}$. The obtained solution was filtered $0.45 \mu \mathrm{m}$ PET filter and transferred to HPLC vials (the concentration of solution $2.0 \mathrm{mg} / \mathrm{ml}$ ). The same procedure was applied to the placebo.

\section{Basic condition}

The pulverized RNZ ER tablets, equivalent to $200 \mathrm{mg}$ RNZ was weighed to a $100 \mathrm{ml}$ volumetric flask and, then $20 \mathrm{ml}$ ammonium dihydrogen phosphate solution was added to the flask and kept in an ultrasonic bath for $15 \mathrm{~min}$. Then $10 \mathrm{ml}$ methanol was added to flask and kept in ultrasonic bath for $1 \mathrm{~min}$. Afterward $15.0 \mathrm{ml} 1 \mathrm{~N} \mathrm{NaOH}$ was added. The prepared solution-maintained room temperature for 24 hours. At the end of time the solution was neutralized with $15.0 \mathrm{ml} 1 \mathrm{~N} \mathrm{HCl}$ and the volumetric flask was complemented with ammonium dihydrogen phosphate solution to designated volume. The flask was kept in an ultrasonic bath for $15 \mathrm{~min}$. The obtained solution was filtered through $0.45 \mu \mathrm{m}$ PET filter and transferred to HPLC vials (the concentration of solution $2.0 \mathrm{mg} /$ $\mathrm{ml})$. The same procedure was applied to the placebo.

\section{Oxidative condition}

The pulverized RNZ ER tablets, equivalent to $200 \mathrm{mg}$ RNZ was weighed to a $100 \mathrm{ml}$ volumetric flask and then $20 \mathrm{ml}$ ammonium dihydrogen phosphate solution was added to the flask, and kept in an ultrasonic bath for $15 \mathrm{~min}$. Then $10 \mathrm{ml}$ methanol was added to the flask and kept in ultrasonic bath for $1 \mathrm{~min}$. Afterward $15.0 \mathrm{ml} \mathrm{H}_{2} \mathrm{O}_{2} 30 \%$ was added. The prepared solution-maintained room 
temperature for 24 hours. At the end of time the volumetric flask was complemented with ammonium dihydrogen phosphate solution to designated volume. The flask was kept in an ultrasonic bath for $15 \mathrm{~min}$. The obtained solution was filtered $0.45 \mu \mathrm{m}$ PET filter and transferred to HPLC vials (the concentration of solution $2.0 \mathrm{mg} / \mathrm{ml}$ ). The same procedure was applied to the placebo.

\section{Thermal condition}

RNZ ER tablets and placebo were kept at $60^{\circ} \mathrm{C} \pm 2{ }^{\circ} \mathrm{C}$ in the oven for a week. At the end of the time the pulverized RNZ ER tablets, equivalent to $200 \mathrm{mg}$ RNZ was weighed to a $100 \mathrm{ml}$ volumetric flask, and then $70 \mathrm{ml}$ ammonium dihydrogen phosphate solution was added to the flask and kept in an ultrasonic bath for $10 \mathrm{~min}$. The solution was kept at room temperature for $5 \mathrm{~min}$ and complemented with ammonium dihydrogen phosphate solution to designated volume. The flask was kept in an ultrasonic bath for $10 \mathrm{~min}$. The obtained solution was filtered $0.45 \mu \mathrm{m}$ PET filter and transferred to HPLC vials (the concentration of solution $2.0 \mathrm{mg} / \mathrm{ml}$ ). The same procedure was applied to the placebo.

\section{Light (1.2 million lux hours)}

RNZ ER tablets and placebo were exposed to light for 24 hours (1.2 million lux hours). The procedure applied according to ICH guideline Q1B. At the end of the time the pulverized RNZ ER tablets, equivalent to $200 \mathrm{mg}$ RNZ was weighed to a $100 \mathrm{ml}$ volumetric flask and then $70 \mathrm{ml}$ ammonium dihydrogen phosphate solution was added to the flask and kept in an ultrasonic bath for $10 \mathrm{~min}$. The solution was kept at room temperature for $5 \mathrm{~min}$ and complemented with ammonium dihydrogen phosphate solution to designated volume. The flask was kept in an ultrasonic bath for $10 \mathrm{~min}$. The obtained solution was filtered 0.45 $\mu \mathrm{m}$ PET filter and transferred to HPLC vials (the concentration of solution 2.0 $\mathrm{mg} / \mathrm{ml}$ ). The same procedure was applied to the placebo.

\section{RESULTS and DISCUSSION}

\section{Method optimization}

In order to optimize the assay method, several mobile phase solvents were tested. In this context $0.1 \mathrm{~N} \mathrm{HCl}, \mathrm{pH} 6.8$ phosphate buffer, acetonitrile: buffer (ammonium dihydrogen phosphate) (80:20), methanol: water (80:20), acetonitrile: water (80:20), acetonitrile: $\mathrm{pH} 6.8$ phosphate buffer (80:20), acetonitrile: 0.1 $\mathrm{N} \mathrm{HCl}(80: 20)$ were tried and the condition that enabled a suitable resolution and shape of peaks was acetonitrile: buffer (80:20). Also different sample and standard preparation solvents: acetonitrile $+0.1 \mathrm{~N} \mathrm{HCl}(1: 10)$; water $+0.1 \mathrm{~N} \mathrm{HCl}$ (1:5); mobile phase and different sample preparation processes (mixing with vor- 
tex, keeping in an ultrasonic bath) were tried. The results of the analysis of these changes showed that for sample preparation RNZ ER tablet using mobile phase and for standard preparation using $0.1 \mathrm{~N} \mathrm{HCl}$ as described at 2.4. Preparation of standard and sample solutions were the best way of solving RNZ.

To optimize and validate the analytical method of RNZ impurities for RNZ ER tablets, data obtained from AARTI Healthcare Related Substances Analytical Method was modified and used.

The obtained features provided the chromatogram reported in Figure.2. a good peak shape and peak resolution were obtained within acceptable analysis time (20 $\mathrm{min})$.

\section{Method validation}

\section{Selectivity}

To assess the selectivity of the method, placebo solution, mobile phases, sample solution of RNZ ER tablet, RNZ WS, Zen-I, Zen-II, and Zen-III impurity solutions were injected in duplicate and ability of chromatographic separation of each sample was evaluated. The chromatogram shown Figure. 2 was obtained. Five peaks were obtained from the chromatogram. Between the peaks of RNZ, solvent, mobile phases, placebo and impurities did not observe any interference. All peaks completely separated from another one.


Figure 2. HPLC chromatogram $(\lambda=220 \mathrm{~nm})$ of a solution containing RNZ ER tablet, impurities Zen-I, Zen-II and Zen-III. 


\section{Linearity}

The linearity of the method was evaluated for five concentration levels by diluting the standard stock solution corresponding to $20,50,80,100$, and $120 \%$. The prepared solutions were filtered and injected in triplicate. For impurities, response and correction factor were calculated using the formula shown below:

$$
\mathrm{RRF}=\frac{m_{i}}{m_{s}} \quad \mathrm{CF}=\frac{1}{R R F}
$$

RRF: Response factor

CF: Correction factor

$m_{i}$ : the slope value obtained from the calibration curve of the impurity standard solutions

$\mathrm{m}_{\mathrm{s}}$ : the slope value obtained from the calibration curve of the active substance standard solutions

The obtained data showed that in the expected concentration RNZ and its impurities are linear. The summary of the results is reported in Table 2. The determination coefficient of all compounds was found greater than 0,9999 , these results show the precision of the proposed methods ${ }^{22}$.

Table 2. The summary of five levels calibration graphs for RNZ, Zen-I, Zen-II and Zen-III $(y=a x+b)$, three replicates for each level $(n=15)$.

\begin{tabular}{ccccc}
\hline & RNZ & Zen-I & Zen-II & Zen-III \\
\hline Range $(\mu \mathrm{g} / \mathrm{ml})$ & $50-300$ & $0.09-5.76$ & $0.07-5.97$ & $0.07-6.01$ \\
Slope $(\mathrm{a})$ & 20801294.3595 & 40503993.06 & 83381036.74 & 63496097.58 \\
Intercept $(\mathrm{b})$ & 5977.0612 & 2263.45 & 1162.55 & 879.75 \\
$\mathrm{r}^{2}$ & 0.9998 & 1.00 & 1.00 & 1.00 \\
RRF & - & 0.70 & 1.44 & 1.09 \\
CF & - & 1.43 & 0.70 & 0.91 \\
StDev* & 229 & 303 & 401 & 179 \\
95\% Cl for $\mu^{*}$ & $(114617 ; 115135)$ & $(111394 ; 112081)$ & $(247206 ; 248114)$ & $(190099 ; 190505)$ \\
SE Mean* & 132 & 175 & 232 & 103 \\
* & & & &
\end{tabular}




\section{Accuracy}

To assess the accuracy of the method, three parallel samples are prepared by spiking the placebo with known amounts of RNZ WS 80, 100, $120 \%$. For impurities with the known amounts Zen-I WS, Zen-II WS, and Zen-III WS, LOQ, 100 , and $200 \%$ solutions were prepared. Three injections from each sample were run on HPLC. The recovery values were calculated according to the standard solution. The obtained results of accuracy studies were shown in Table 3.

Table 3. The summary of accuracy studies for RNZ and its impurities Zen-I, Zen-II and Zen-III

\begin{tabular}{|c|c|c|c|c|c|c|c|}
\hline $\begin{array}{c}\text { RNZ } \\
\text { Level \% }\end{array}$ & $\begin{array}{l}\text { Concentration } \\
(\mathrm{mg} / \mathrm{ml})\end{array}$ & $\begin{array}{c}\text { Recovery } \\
\%\end{array}$ & Mean \% & $\begin{array}{c}\text { Zen-I } \\
\text { Level \% }\end{array}$ & $\begin{array}{c}\text { Concentration } \\
(\mu \mathrm{g} / \mathrm{ml})\end{array}$ & $\begin{array}{c}\text { Recovery } \\
\%\end{array}$ & Mean \% \\
\hline 80 & 0.20 & $\begin{array}{l}100.5 \\
100.1 \\
100.8\end{array}$ & 100.5 & LOQ & 0.096 & $\begin{array}{l}98.6 \\
98.0 \\
97.1\end{array}$ & 97.9 \\
\hline 100 & 0.25 & $\begin{array}{c}99.9 \\
99.9 \\
100.2\end{array}$ & 100.0 & 100 & 3.000 & $\begin{array}{l}93.3 \\
92.9 \\
90.1\end{array}$ & 92.1 \\
\hline 120 & 0.30 & $\begin{array}{c}100.2 \\
99.9 \\
98.8\end{array}$ & 99.6 & 200 & 6.000 & $\begin{array}{l}84.6 \\
90.3 \\
90.5\end{array}$ & 88.47 \\
\hline $\begin{array}{c}\text { Zen-II } \\
\text { Level \% }\end{array}$ & $\begin{array}{l}\text { Concentration } \\
\qquad(\mu \mathrm{g} / \mathrm{ml})\end{array}$ & $\begin{array}{c}\text { Recovery } \\
\%\end{array}$ & Mean \% & $\begin{array}{l}\text { Zen-III } \\
\text { Level \% }\end{array}$ & $\begin{array}{l}\text { Concentration } \\
(\mu \mathrm{g} / \mathrm{ml})\end{array}$ & $\begin{array}{c}\text { Recovery } \\
\%\end{array}$ & Mean \% \\
\hline LOQ & 0.096 & $\begin{array}{l}85.6 \\
98.0 \\
84.6\end{array}$ & 89.4 & LOQ & 0.096 & $\begin{array}{l}102.6 \\
103.6 \\
103.2 \\
\end{array}$ & 103.1 \\
\hline 100 & 3.000 & $\begin{array}{c}100.9 \\
102.2 \\
98.7\end{array}$ & 100.6 & 100 & 3.000 & $\begin{array}{l}96.4 \\
96.6 \\
95.2\end{array}$ & 96.1 \\
\hline 200 & 6.000 & $\begin{array}{c}92.6 \\
99.2 \\
100.0\end{array}$ & 97.3 & 200 & 6.000 & $\begin{array}{l}91.3 \\
99.1 \\
99.5\end{array}$ & 96.6 \\
\hline
\end{tabular}

\section{Robustness}

To determine the robustness of the method, the effect of different flow rates (o.8 - $1.2 \mathrm{ml} / \mathrm{min}$ ), column temperature $\left(28-32{ }^{\circ} \mathrm{C}\right.$ ), and filter (Nylon - PET - RC) were evaluated. The consistency between the results without changing the analysis conditions and the results found after the change was evaluated. For the method of RNZ impurities the effect of different wavelength (208 nm$212 \mathrm{~nm}$ ) and filter (RC - PET) were evaluated. The obtained data of robustness studies summarized in Table 4 and 5 . 
Table 4. The summary of robustness studies for RNZ

\begin{tabular}{cccccc}
\hline Factor & Flow rate & $\begin{array}{c}\text { Column } \\
\text { Temperature }{ }^{\circ} \mathbf{C}\end{array}$ & Filter & RRT (min) & *Conformity \% \\
\hline \multirow{2}{*}{ Flow Rate } & $1.0 \mathrm{mg} / \mathrm{ml}$ & & & 4.204 & - \\
& $0.8 \mathrm{mg} / \mathrm{ml}$ & 30 & PET & 5.159 & 99.0 \\
& $1.2 \mathrm{mg} / \mathrm{ml}$ & & 3.464 & 99.3 \\
\hline \multirow{2}{*}{ Column Temperature } & $1.0 \mathrm{mg} / \mathrm{ml}$ & 30 & & 4.204 & - \\
& & 28 & PET & 4.164 & 99.0 \\
& & 32 & & 4.151 & 99.3 \\
\hline \multirow{2}{*}{ Filter } & $1.0 \mathrm{mg} / \mathrm{ml}$ & 30 & PET & & - \\
& & & Nylon & 4.204 & 100.9 \\
& & & RC & & 100.5 \\
\hline
\end{tabular}

* conformity is a description of how the change rate fits with the routine of the study

Table 5. The summary of robustness studies for Zen-I, Zen-II and Zen-III

\begin{tabular}{|c|c|c|c|c|c|c|c|}
\hline Factor & $\begin{array}{c}\text { Flow rate } \\
(\mathrm{mg} / \mathrm{ml})\end{array}$ & $\begin{array}{l}\text { Column } \\
\text { Tempera- } \\
\text { ture }\left({ }^{\circ} \mathrm{C}\right)\end{array}$ & Filter & $\lambda(\mathrm{nm})$ & $\begin{array}{c}\text { Conformity } \\
\text { Zen-I } \\
\%^{*}\end{array}$ & $\begin{array}{c}\text { Conformity } \\
\text { Zen-II } \\
\%^{*}\end{array}$ & $\begin{array}{c}\text { Conformity } \\
\text { Zen-III } \\
\%{ }^{*}\end{array}$ \\
\hline & & & & 210 & - & - & - \\
\hline \multirow[t]{3}{*}{ Wavelength } & 1.0 & 30 & PET & 208 & 100.8 & 98.6 & 102.0 \\
\hline & & & & 212 & 102.2 & 99.5 & 98.0 \\
\hline & & & PET & & - & - & - \\
\hline \multirow[t]{2}{*}{ Filter } & 1.0 & 30 & Nylon & 210 & 100.1 & 101.9 & 101.8 \\
\hline & & & $\mathrm{RC}$ & & 100.0 & 100.0 & 100.0 \\
\hline
\end{tabular}

* conformity is a description of how the change rate fits with the routine of the study

\section{Precision}

The precision of the method was evaluated at three levels: repeatability, intermediate precision and, reproducibility. To assess the reproducibility six separate sample solutions were run on HPLC. Two injections were made for each sample. To assess the repeatability of the method six separate standard solutions were run on HPLC. Field values were evaluated as a result of sequential injections. To evaluate the intermediate precision of the method, the samples identified in the method accuracy were prepared by a different analyst. The samples were injected into a different HPLC system. Quantity values were calculated for each sample. The RSD values obtained from twelve samples were evaluated. The low RSD values of the precision studies indicate that the method is precise ${ }^{23}$. As a System Suitability Parameters, the RSD value of the peak areas 
obtained from six measurements of the standard solution should be a maximum of 5.0\%. The results are given in the Table 6-8.

Table 6. Results of reproducibility studies for RNZ and its impurities Zen-I, Zen-II and Zen-III

\begin{tabular}{ccccc}
\hline Sample No & $\begin{array}{c}\text { RNZ } \\
\text { Result (\%) }\end{array}$ & $\begin{array}{c}\text { Zen-I } \\
\text { Recovery (\%) }\end{array}$ & $\begin{array}{c}\text { Zen-II } \\
\text { Recovery (\%) }\end{array}$ & $\begin{array}{c}\text { Zen-III } \\
\text { Recovery (\%) }\end{array}$ \\
\hline 1 & 96.7 & 96.1 & 101.4 & 101.8 \\
2 & 97.4 & 96.5 & 102.7 & 102.9 \\
3 & 97.5 & 94.2 & 98.6 & 98.7 \\
4 & 98.6 & 94.7 & 99.5 & 99.9 \\
5 & 97.5 & 100.4 & 104.6 & 106.0 \\
6 & 97.9 & 99.7 & 104.3 & 104.1 \\
Mean & 97.6 & 96.9 & 101.9 & 102.2 \\
RSD \% & 0.7 & 2.7 & 2.4 & 2.6
\end{tabular}

Table 7. Results of repeatability studies for RNZ and its impurity standard

\begin{tabular}{ccc}
\hline Sample No & RNZ & RNZ Impurity Standard \\
& Peak Area & 115881 \\
\hline 1 & 5123875 & 115681 \\
2 & 5096835 & 115363 \\
3 & 5109472 & 114367 \\
4 & 5092544 & 115862 \\
5 & 5094318 & 115198 \\
6 & 5109169 &
\end{tabular}

Table 8. Results of intermediate precision studies for RNZ and its impurities Zen-I, Zen-II and Zen-III

\begin{tabular}{|c|c|c|c|c|c|c|c|c|}
\hline \multirow{3}{*}{$\begin{array}{c}\text { Sample } \\
\text { No }\end{array}$} & \multicolumn{2}{|c|}{ RNZ Result (\%) } & \multicolumn{2}{|c|}{ Zen-I Recovery (\%) } & \multicolumn{2}{|c|}{ Zen-II Recovery (\%) } & \multicolumn{2}{|c|}{ Zen-III Recovery (\%) } \\
\hline & $\begin{array}{l}1^{\text {st }} \text { ana- } \\
\text { lyst }\end{array}$ & $\begin{array}{c}2^{\text {nd }} \\
\text { analyst }\end{array}$ & $\begin{array}{l}1^{\text {st }} \text { ana- } \\
\text { lyst }\end{array}$ & $\begin{array}{c}2^{\text {nd }} \\
\text { analyst }\end{array}$ & $\begin{array}{l}1^{\text {st }} \text { ana- } \\
\text { lyst }\end{array}$ & $\begin{array}{c}2^{\text {nd }} \\
\text { analyst }\end{array}$ & $\begin{array}{l}1^{\text {st }} \text { ana- } \\
\text { lyst }\end{array}$ & $\begin{array}{c}2^{\text {nd }} \\
\text { analyst }\end{array}$ \\
\hline & $\begin{array}{l}\text { Instru- } \\
\text { ment A }\end{array}$ & $\begin{array}{l}\text { Instru- } \\
\text { ment B }\end{array}$ & $\begin{array}{l}\text { Instru- } \\
\text { ment A }\end{array}$ & $\begin{array}{l}\text { Instru- } \\
\text { ment B }\end{array}$ & $\begin{array}{l}\text { Instru- } \\
\text { ment A }\end{array}$ & $\begin{array}{l}\text { Instru- } \\
\text { ment B }\end{array}$ & $\begin{array}{l}\text { Instru- } \\
\text { ment A }\end{array}$ & $\begin{array}{l}\text { Instru- } \\
\text { ment B }\end{array}$ \\
\hline 1 & 96.7 & 96.8 & 96.1 & 94.5 & 101.4 & 100.9 & 101.8 & 99.4 \\
\hline 2 & 97.4 & 95.6 & 96.5 & 94.8 & 102.7 & 103.5 & 102.9 & 100.4 \\
\hline 3 & 97.5 & 96.9 & 94.2 & 94.3 & 98.6 & 100.3 & 98.7 & 99.1 \\
\hline 4 & 98.6 & 95.8 & 94.7 & 94.6 & 99.5 & 98.8 & 99.9 & 100.9 \\
\hline 5 & 97.5 & 95.1 & 100.4 & 94.4 & 104.6 & 99.4 & 106.0 & 99.1 \\
\hline 6 & 97.9 & 96.6 & 99.7 & 94.3 & 104.3 & 99.6 & 104.1 & 101.9 \\
\hline Mean & 97.6 & 96.1 & 96.9 & 94.5 & 101.9 & 100.4 & 102.2 & 100.1 \\
\hline RSD \% & 0.7 & 1.0 & 2.7 & 0.2 & 2.4 & 1.7 & 2.6 & 1.1 \\
\hline
\end{tabular}




\section{Limit of quantification and detection}

The LOD and LOQ concentrations were obtained from the linearity studies. It is found by calculating the signal to noise ratio (LOD: signal to noise ratio $=3$; LOQ: signal to noise ratio $=10$ ). Data obtained of LOD and LOQ for RNZ and its impurities Zen-I, Zen-II, and Zen-III were showed in Table 9.

Table 9. Results of LOD and LOQ studies for RNZ and its impurities Zen-I, Zen-II and Zen-III

\begin{tabular}{ccccc}
\hline Sample & LOD \% & $\begin{array}{c}\text { LOQ Mean Peak Area / } \\
\text { RSD \% }\end{array}$ & LOQ $(\mathbf{m g} / \mathbf{m L})$ & LOD $(\mathbf{m g} / \mathbf{m L})$ \\
\hline RNZ & 0.002 & $2357 / 5.6$ & 0,0000399 & 0,000012 \\
Zen-I & 0.005 & $3607 / 2.9$ & 0,0000960 & 0,000029 \\
Zen-II & 0.004 & $4753 / 3.1$ & 0,0000717 & 0,000022 \\
Zen-III & 0.004 & $4619 / 1.8$ & 0,0000722 & 0,000022
\end{tabular}

\section{Forced degradation}

RNZ ER tablets were exposed to heat, light, acid, base, and oxidation. Impurity analyses were performed before and after exposure. The analysis results were given in Table 10.

A comprehensive stability study was performed including forced degradation studies. A highly sensitive, simple HPLC-UV method developed and validated for the determination of ranolazine and its impurities. The method validation was performed in accordance with ICH guidelines. The highest degradation occurred in the $\mathrm{H}_{2} \mathrm{O}_{2}$ environment, indicating that Ranolazine is highly sensitive to the oxygen ${ }^{24}$.

\section{ACKNOWLEDGEMENTS}

The authors would like to give sincere thanks to Biofarma Pharmaceutical Company for financial support and also for using the R\&D facility for all of the analyses were performed. 


\section{REFERENCES}

1. Dobesh, PP, Trujillo TC. Ranolazine: a new option in the management of chronic stable angina. Pharmacotherapy, 2007; 27(12): 1659-1676. doi: 10.1592/phco.27.12.1659.

2. Ranolazine, Medscape, 2016; Availiable from: https://reference.medscape.com/. Accessed on: 01.05.2017

3. Dobrev D, Nattel S. New antiarrhythmic drugs for treatment of atrial fibrillation, new drug class. Lancet. 2010; 375: 1212- 1223.

4. Pubchem, Ranolazine chemical structure, 2020; Available from: https://pubchem.ncbi. nlm.nih.gov/compound/Ranolazine. Accessed on: 22.09.2020

5. Moen AR, Karstad R, Anthonsen T. Chemo-Enzymatic synthesis of both enantiomers of the anti-anginal drug ranolazine. Biocatal Biotransfor, 20o5; 23(1): 45-51. https://doi. org/10.1080/10242420500067357

6. Jerling M. Clinical pharmacokinetics of ranolazine. Clin Pharmacokinet, 2oo6; 45(5): 469491. https://doi: 10.2165/o0003088-200645050-00003.

7. Thireau J, Pasquie J, Martel E, Guennec J, Richard S. New drugs vs. old concepts: a fresh look at antiarrhythmics. Pharmacol Therapeut, 2011; 132: 125-145. https://doi: 10.1016/j. pharmthera.2011.03.003.

8. Szél T, Koncz I, Jost N, Baczkó I, Husti Z, Virág L et al. Class I/B antiarrhythmic property of ranolazine, a novel antianginal agent, in dog and human cardiac preparations. Eur J Pharmacol, 2011; 662 (1-3): 31-39. https://doi: 10.1016/j.ejphar.2011.04.042.

9. Ranexa ${ }^{\mathrm{TM}}$ Extended Release Tablets, FDA, Accessdata, Available from: https://www.accessdata.fda.gov/drugsatfda_docs/label/2016/021526so29lbl.pdf . Accessed on: 05.05.2018.

10. Cattaneo M, Poretta AP, Gallino A. Ranolazine: Drug overview and possible role in primary microvascular angina management. Int J Cardiol, 2015; 181: 376-381. https://doi. org/10.1016/j.jicard.2014.12.055

11. Kosiborod M, Arnold SV, Spertus JA, McGuire DK, Li Y, Yue P et al. Evaluation of ranolazine in patients with type 2 diabetes mellitus and chronic stable angina. J Am Coll Cardiol, 2013; 61: 2038 - 2045. https://doi: 10.1016/j.jacc.2013.02.011

12. Keating GM. Ranolazine: A Review of its use as add-on therapy in patients with chronic stable angina pectoris. Adis Drug Evaluation, 2013; 73: 55-73. https://doi: 10.1007/s40265012-0005-z.

13. Truffa AM, Newby LK, Melloni C. Extended-release ranolazine: critical evaluation of its use in stable angina. Vasc Health Risk Manag. 2011; 7: 535-539. https://doi: 10.2147/VHRM. S15560

14. Tegk M, Mukkala BVP, Babu S. Formulation and evaluation of ranolazine extended release tablets: influence of polymers. Asian J Pharm Sci, 2o11; 5: 162-166.

15. Deepika D. Formulation and evaluation of film coated ranolazine sustained release matrix tablets. Int J Appl, 2015; 2(5): 38-53.

16. Kumari MV, Reddy PV, Sudhakar M. Formulation and evaluation of sustained release matrix tablets of ranolazine. Int J Pharm, 2012; 2(1): 224-229.

17. Bidada J, Gonjari I, Bhusari A, Raut C, Dhule A. Development of extended release matrix tablets of ranolazine containing polyacrylic and ethylcellulose polymers. Der Pharmacia Lettre. 2011; 3(4): 215-226. 
18. Asaduzzaman Rahman R, Khan SR, Islam A. Development of sustained release matrix tablet of ranolazine based on methocel $\mathrm{K}_{4} \mathrm{M} \mathrm{CR}$, in vitro drug release and kinetic approach. J. Appl Pharm Sci, 2o11; 01(08): 131-136.

19. Rahman M, Jha MK, Ahsan Q, Begum T. Effect of various grades of hydroxypropylmethylcellulose matrix systems as oral sustained release drug delivery systems for ranolazine. Journal of Pharmaceutics and Cosmetology, 2011; 1(2): 82-92.

20. ICH Q2, Validation of Analytical Procedures: Text And Methodology, 2oo5, Available from: https://database.ich.org/sites/default/files/Q2\%28R1\%29\%20Guideline.pdf. Accessed on: 01.06.2017.

21. ICH Q3B, Impurities in New Drug Products Q3B, 2006, Available from: https://database. ich.org/sites/default/files/Q3B\%28R2\%29\%20Guideline.pdf. Accessed on: 01.07.2017.

22. Esim Ö, Gümüştaş M, Hasçiçek C, Özkan SA. A novel stability-indicating analytical method development for simultaneous determination of carboplatin and decitabine from nanoparticles. J Sep Sci, 2020; 43(17): 3491-3498. https://doi.org/10.1002/jssc.202000320

23. Dinesh ND, Vishukumar BK, Nagaraja P, Made Gowda NM, Rangappa RK. Stability indicating RP-LC determination of sildenafil citrate (Viagra) in pure form and in pharmaceutical samples. J Pharm Biomed Anal, 2020; 29(4): 743-748. https://doi: 10.1016/so7317085(02)00123-1

24. Kurmi M, Kumar S, Singh B, Singh S. Implementation of design of experiments for optimization of forced degradation conditions and development of a stability-indicating method for furosemide. J Pharm Biomed Anal, 2014; 96: 135-143. https://doi: 10.1016/j.jpba.2014.03.035 